\title{
EXAMINATION OF THE HYPOTHESIS THAT A DIRECT CONTROL SYSTEM EXISTS FOR THE PROSTATE AND SEMINAL VESICLES
}

\author{
C. G. PIERREPOINT, P. DAVIES, M. H. LEWIS* \\ AND D. B. MOFFAT* \\ Tenovus Institute for Cancer Research, The Heath, Cardiff CF4 $4 X X$, \\ and ${ }^{*}$ Department of Anatomy, University College, Cardiff
}

Species predisposition to various diseases can at times be related to ecological factors such as the immediate environment, the life-style and diet or to inherent biochemical make-up or anatomical configuration. It is, however, as yet unexplained why man and dog appear to be alone in the animal kingdom in their susceptibility to prostatic hypertrophy. The gland appears to be unequivocal in its essential function and is universally androgen-dependent. It is of interest therefore to determine any common factor that discriminates against animals of these two species and leaves all others apparently immune.

The prostate of man and dog, unlike that of the bull, boar, stallion and ram, is compact and the ductus deferentes pass through it to reach the urethra (Text-fig. 1). Prostatic hypertrophy becomes clinically important, however, because the gland completely encircles the urethra and base of bladder in man and dog causing constriction and urinary obstruction.

Macroscopically, the prostate of the cat seems similar but transverse sections of the gland show that the deferent ducts pass centrally between what appear to be two dorsolaterally placed lobes (unpublished observations). Were the cat also to be subject to prostatic hypertrophy the condition may thus not be recognizable clinically. Certainly no case report can be found in the literature.

The present investigations were undertaken to examine the possibility that the particular distribution of the ductus deferens might have some bearing on prostatic function, perhaps by providing the means for transport of androgens from their source directly and in high concentrations rather than by dilution through the general circulation. Skinner \& Rowson (1968a, b) have previously indicated that the ampullae of the ram were under some local influence and concluded that some testosterone might normally pass along the ductus deferens in the testicular fluid.

The procedures used in the present experiments to investigate the effects of various surgical ablations on the activity of RNA polymerase are outlined schematically in Text-fig. 2. Aseptic conditions were adopted at all times and no case of cryptorchidism was found as a result of surgery. Heller \& Rothchild (1974) have reported that vasectomy performed without due surgical cleanliness could result in reduced testicular weight.

Unilateral surgery was performed whenever possible so that any concomitant 


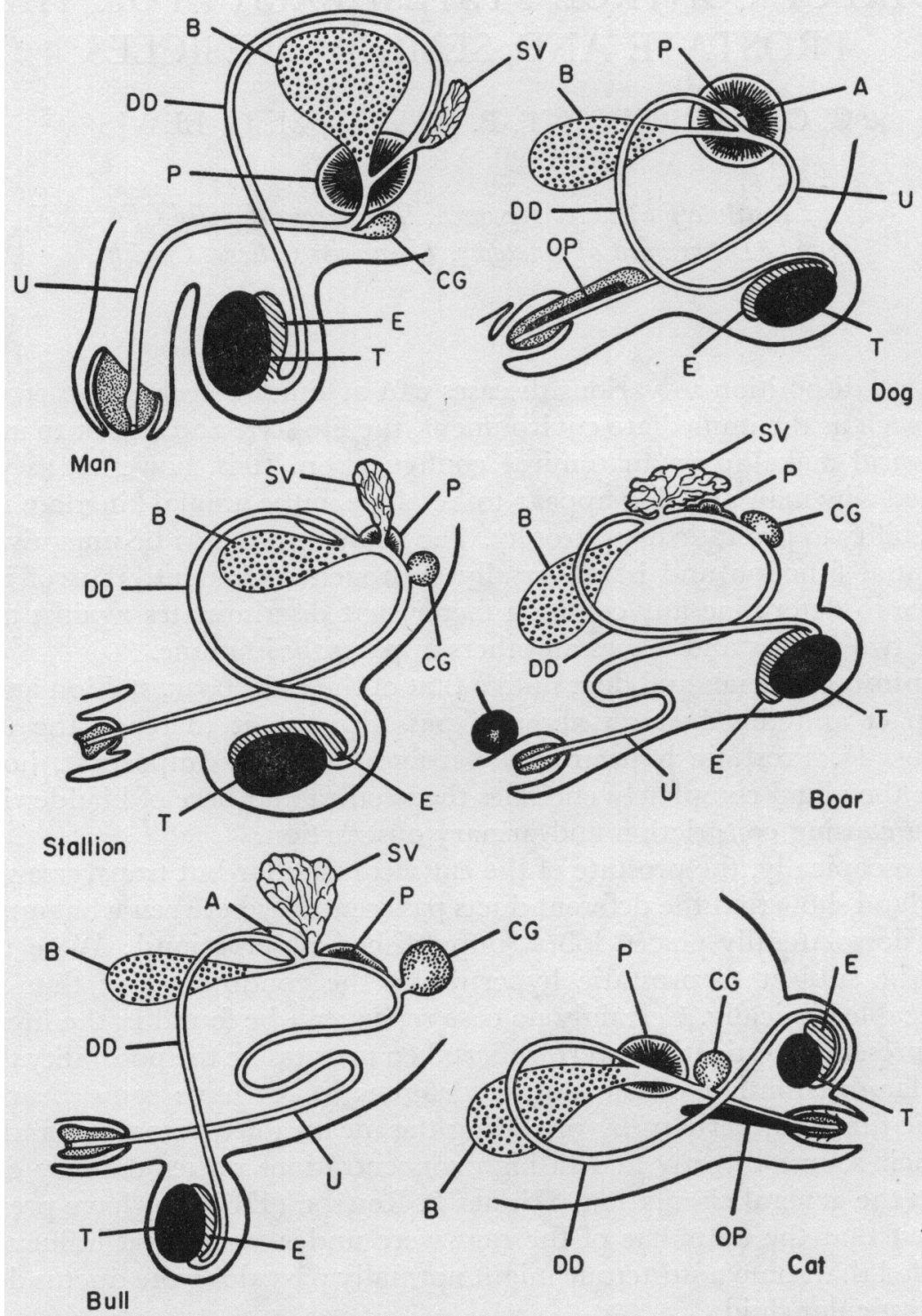

TEXT-FIG. 1. Schematic representation (modified after Nalbandov, 1964) of the genital tracts of man, dog, stallion, boar, bull and tom cat. Note the passage of the ductus deferens through the prostates of man and dog compared with those of the other domestic animals. A, ampulla: B, bladder: CG, Cowper's gland: DD, ductus deferens: $\mathrm{E}$, epididymis: $\mathrm{OP}$, os penis: $\mathrm{P}$, prostate: $\mathrm{SV}$, seminal vesicle: $T$, testis: $U$, urethra. 


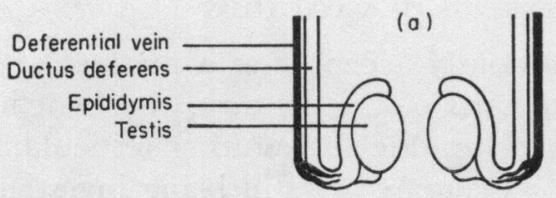

(b)
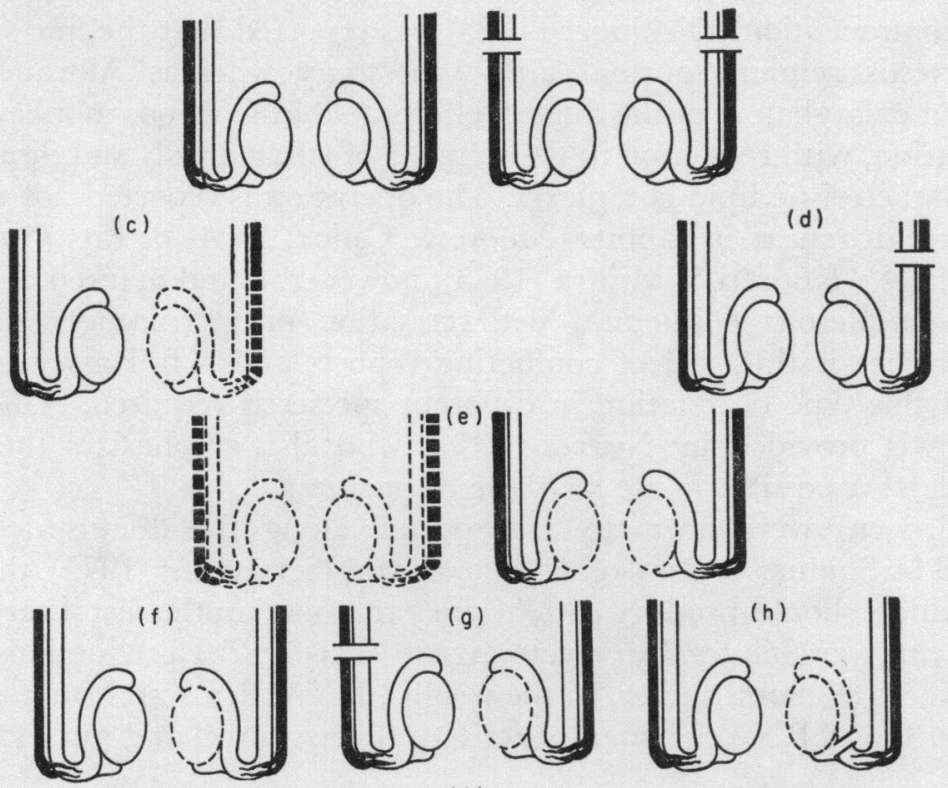

(h)
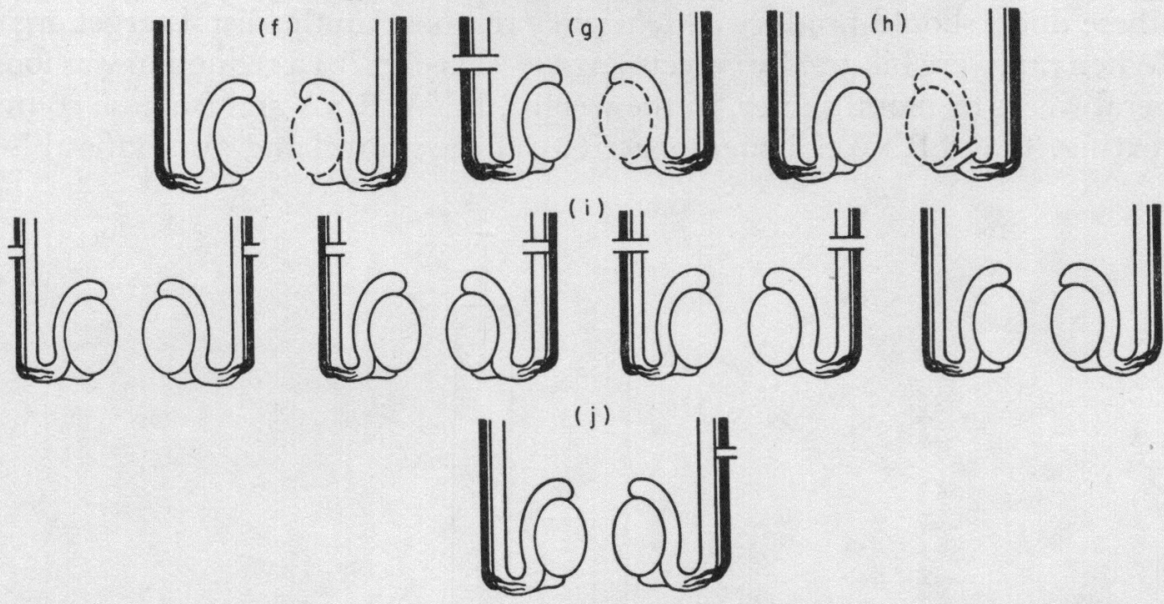

TExT-FIG. 2. Schematic representation of the surgical procedures adopted for the experiments described in this paper. (a) Normal genital system of the rat; (b) bilateral vasectomy compared with sham operation; (c) unilateral orchido-epididymidectomy; (d) unilateral vasectomy; (e) bilateral orchidectomy compared with bilateral orchido-epididymidectomy; (f) unilateral orchidectomy; (g) unilateral orchidectomy compared with contralateral vasectomy; $(h)$ unilateral orchidectomy and removal of the caput and corpus epididymidis; (i) bilateral ligation of the deferential veins, the vasa alone, both vasa and veins and sham operation; $(j)$ unilateral deferential venotomy. 
changes in circulating hormone levels could be obviated and the effects assessed by comparison of the left and right lobes of the prostate and seminal vesicles.

THE EFFECTS OF VASECTOMY

When castration was being cautiously accepted as a method of treatment for human prostatic disease at the turn of the century, the beneficial effects of vasectomy were discounted as being due to resulting testicular atrophy (see Wallace, 1905). The effects of vasectomy are still being investigated in detail although the practice is being vigorously publicized as an ideal means of human contraception. Flickinger (1973) has reported that the fine structure of the rat testis remains normal after vasectomy whereas Alexander (1972) has shown enlargement of the ductuli efferentes of the rhesus monkey following vasal ligation, with reduction in the number of ciliated cells and disappearance of the characteristic lipid complexes. The operation is reported not to interfere with spermatogenesis in rabbits (Moore \& Quick, 1924) or rats (Smith, 1962; Neaves, 1974). Kothari \& Mishra (1973), however, found marked degeneration of the seminiferous epithelium with cessation of spermatogenesis in dogs. The literature is thus full of conflicting reports and a full assessment of the effects of this type of ablation in different species is required. A fuller list of references is provided by Neaves (1974) who also emphasizes the operative procedure as a possible cause for these disparities.

If androgens were normally transported along the ductus deferentes as suggested by Skinner \& Rowson (1968a, b) and Pierrepoint (1975), then ligation of these ducts should produce a 'deficiency response' in the distal target organs.

When rats were bilaterally vasectomized (Text-fig. $2 \mathrm{~b}$ ) a reduction was found, several weeks or months later, in the weight, DNA, RNA and fructose contents (Text-fig. 3) and RNA polymerase activity of the ventral and dorsolateral lobes

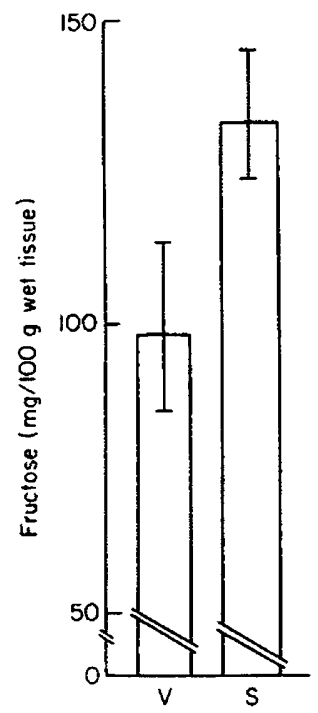

TEXT-FIG. 3. Mean fructose concentrations \pm S.D. in the dorsolateral prostate of three 6 -month-old rats 2 to 3 months after vasectomy $(V)$ or sham operation $(S)(P=0.0474)$. There were three observations in each group. 
of the prostate in comparison with sham-operated animals (Pierrepoint \& Davies, 1973; Pierrepoint, 1975). These results suggested that an 'androgen-deficiency' response had occurred. Mann (1964) observed very high levels of fructose in the ejaculates of vasectomized rams and bulls and Thakur et al. (1972) concluded that vasectomy in the rat increased fructose levels by enhancing androgen production. Skinner \& Rowson (1968a) and Rakha \& Igboeli (1971), on the other hand, found no difference in fructose content of the seminal vesicles after vasectomy. A point to be considered however is that an elevation in fructose concentrations could occur, even though androgenic influences had been reduced, because the spermatozoa which normally catabolize this sugar would no longer be present.

Table 1. Metabolism of $\left[7 \alpha^{3} \mathrm{H}\right]$ testosterone by the prostates of two 8 -month-old rats vasectomized 6 months previously

\begin{tabular}{|c|c|c|c|c|c|c|}
\hline \multirow{2}{*}{ Steroid isolated } & \multicolumn{3}{|c|}{ Vasectomized rats } & \multicolumn{3}{|c|}{ Sham-operated rats } \\
\hline & No. 1 & No. 2 & Mean & No. 1 & No. 2 & Mean \\
\hline $\begin{array}{l}\text { Testosterone (metabolized) } \\
5 \alpha \text {-Dihydrotestosterone } \\
5 \alpha \text {-Androstane } 3 \alpha, 17 \beta \text {-diol } \\
5 \alpha \text {-Androstane- } 3 \beta, 17 \beta \text {-diol }\end{array}$ & $\begin{array}{c}94.5 \\
33.5 \\
6.68 \\
0.80\end{array}$ & $\begin{array}{l}97 \cdot 8 \\
20 \cdot 3 \\
7 \cdot 42 \\
0 \cdot 52\end{array}$ & $\begin{array}{c}96 \cdot 2 \\
26 \cdot 9 \\
7 \cdot 05 \\
0 \cdot 66\end{array}$ & $\begin{array}{c}96 \cdot 5 \\
18 \cdot 6 \\
5 \cdot 63 \\
0 \cdot 59\end{array}$ & $\begin{array}{c}95 \cdot 5 \\
26 \cdot 0 \\
5 \cdot 14 \\
0 \cdot 71\end{array}$ & $\begin{array}{c}96 \cdot 0 \\
22 \cdot 3 \\
5 \cdot 39 \\
0 \cdot 65\end{array}$ \\
\hline
\end{tabular}

The figures represent $\%$ of the initial radioactivity.

The effect of vasectomy on steroid-metabolism in the prostate was examined. Rats aged 2 months were subjected to either bilateral vasectomy (two animals) or bilateral sham operation (two animals). The ventral prostates were removed 6 months after surgery and incubated individually with $10 \mu \mathrm{Ci}\left[7 \alpha-{ }^{3} \mathrm{H}\right]$ testosterone. After $1 \mathrm{hr}$ the reactions were stopped and testosterone, $5 \alpha-$ dihydrotestosterone, $5 \alpha$-androstane- $3 \alpha, 17 \beta$-diol and $5 \alpha$-androstane- $3 \beta, 17 \beta$-diol were isolated and purified, and the \% production or catabolism calculated. The results are shown in Table 1. The extent to which testosterone had been transformed was virtually the same for the vasectomized animals as for the controls $(\sim 96 \%)$. The formation of the expected $5 \alpha$-reduced steroids was also similar in the two pairs of animals. From the variation in the results it is obvious that a larger series is needed to allow a proper evaluation of any real changes, but on these results alone it appears that vasectomy does not have profound effects on steroid metabolism in the prostate.

\section{PROSTATIC RNA POLYMERASE ACTIVITY}

The enzyme RNA polymerase has been shown to be sensitive to changes in the androgenic status of the prostate (Hancock et al., 1962; Williams-Ashman et al., 1964; Liao et al., 1965). It has been used as an assay to investigate relative androgenic activities of steroids (Bashirelahi et al., 1969; Davies et al., 1972; Davies \& Griffiths, 1973a). Prostatic RNA polymerase is probably ultrasensitive to hormonal effects because of the close association of androgenic 
steroids to prostatic chromatin (Fang \& Liao, 1971; Mainwaring \& Peterken, 1971; Steggles et al., 1971) in a tissue-specific manner and alterations in the chromatin template are closely reflected in the activity of the RNA polymerase which transcribes it.

Evidence has been produced for the existence of $\mathrm{Mg}^{2+}$ - and $\mathrm{Mn}^{2+}$-dependent RNA polymerase activity in prostatic nuclei (Mainwaring et al., 1971). Both nucleolar and nucleoplasmic RNA polymerases from the prostate are active in the presence of $\mathrm{Mg}^{2+}$ (Mainwaring et al., 1971; Davies \& Griffiths, 1973b), and changes in the androgenic status of the gland, especially over long periods, are reflected mainly in the activity of the $\mathbf{M g}^{2+}$-dependent enzyme species (Mainwaring et al., 1971).

\section{A UNILATERAL CONTROL SYSTEM}

A unilateral control mechanism was demonstrated (Text-fig. 4) by the fall in the activity of RNA polymerase in the ipsilateral lobes of the prostate and seminal vesicles compared with that in the contralateral lobes after rats were subjected to unilateral castration (ablation of one testis and its epididymis, Text-fig. 2c). Other parameters, not discussed here, also fell (Pierrepoint et al., 1974).

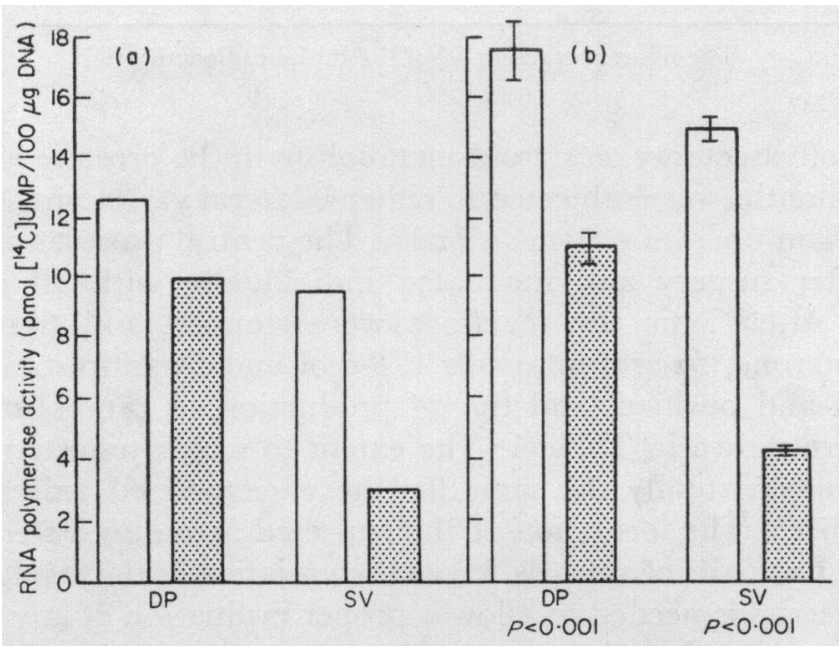

Texr-F1o. 4. The RNA polymerase activity of the ipsilateral (stippled columns) and contralateral (open columns) lobes of the dorsolateral prostate (DP) and seminal vesicles (SV) of rats subjected to unilateral ablation of the testis and epididymis. Vertical bars represent the S.D. (a) Three rats and one observation in each group; (b) nine rats and three observations in each group.

When unilateral vasectomy was performed (Text-fig. 2d), RNA polymerase activity was again reduced in the ipsilateral lobes of the prostate and seminal vesicles, regardless of whether the left (Text-fig. 5a) or the right (Text-fig. 5b) ductus deferens was ligated. These results suggest that a patent ductus deferens does participate in a local manner in the control of the activity of these target organs. 

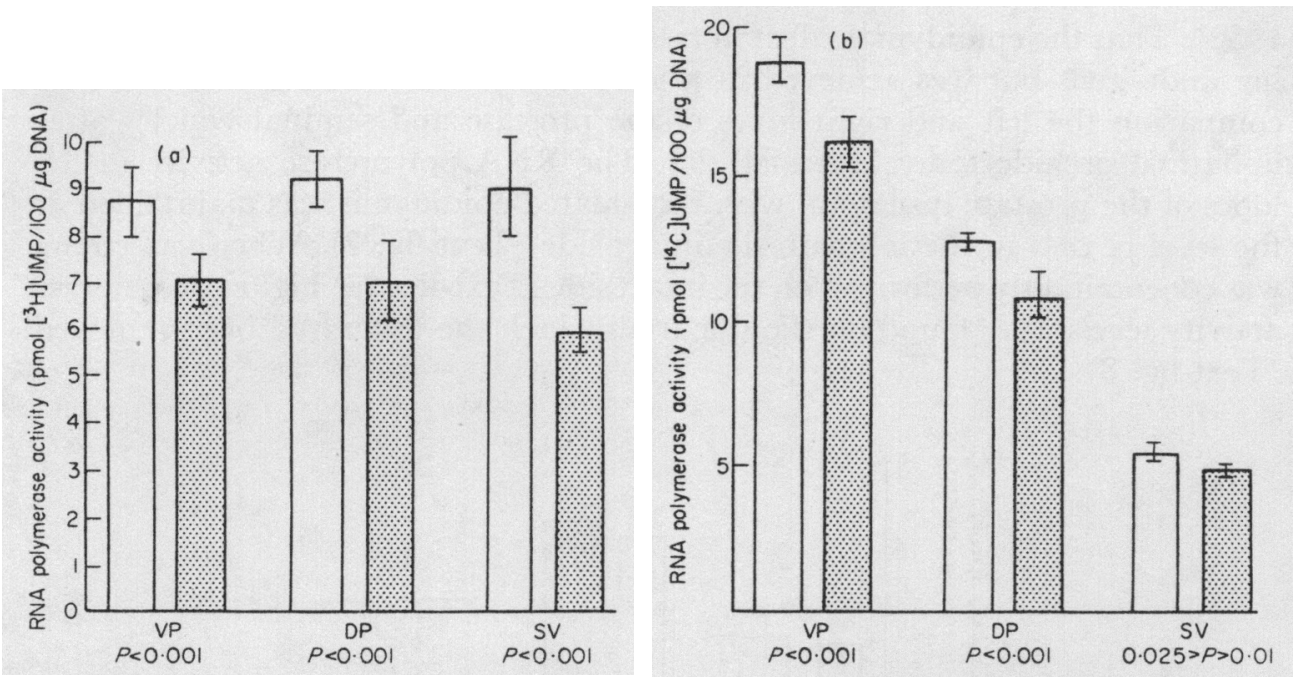

TEXT-FIG. 5. The RNA polymerase activity of the ipsilateral (stippled columns) and the contralateral (open columns) lobes of the ventral prostate (VP), dorsolateral prostate (DP) and seminal vesicles (SV) of rats unilaterally vasectomized on the (a) right side or (b) left side. Vertical bars represent the S.D. There were nine rats and three observations/ group.

Steroids passing along the ductus deferens are assumed to be derived from the epididymis, even if they, or a precursor, were initially synthesized in the testis. The ability of the epididymides to assist in the maintenance of the prostate was investigated by the procedure shown in Text-fig. 2(e). The prostates of those rats subjected to 'total' castration and given exogenous testosterone were found (Text-fig. 6) to be far less active than those from similarly treated rats that were 'incompletely' castrated (testes only removed). Plasma testosterone levels in the latter animals were also found to be higher (Pierrepoint et al., 1974). These findings support the view of horse owners that a horse castrated below the level of epididymis will retain some of the stallion's male propensities (O'Connor,

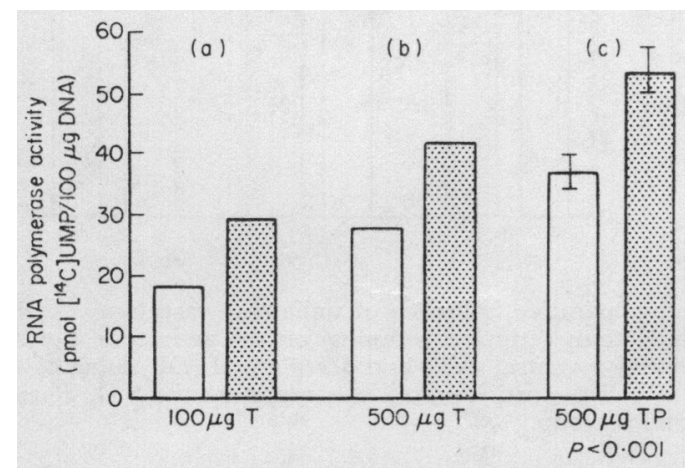

TEXT-FIG. 6. The effect of the presence (stippled columns) or the absence (open columns) of the epididymides on the RNA polymerase activity of the ventral prostate of androgenmaintained rats in which the testes had been removed. $T=$ testosterone; $T P=$ testosterone propionate. Vertical bars represent the S.D. There were six rats and one observation/group for (a) and (b) and six rats and three observations/group for (c). 
1950). That the epididymal effect in rats was not due only to increased circulating androgens but was achieved in a local and direct manner was shown by comparing the left and right lobes of the prostate and seminal vesicles after unilateral orchidectomy (Text-fig. 2f). The RNA polymerase activity in the lobes of the prostate ipsilateral with the isolated epididymis was maintained at the level of that in the lobes on the intact side (Text-fig. 7). When vasectomy was concomitantly performed on the intact side (Text-fig. 2g) higher polymerase activity levels were found on the side from which the testes had been removed (Text-fig. 8).

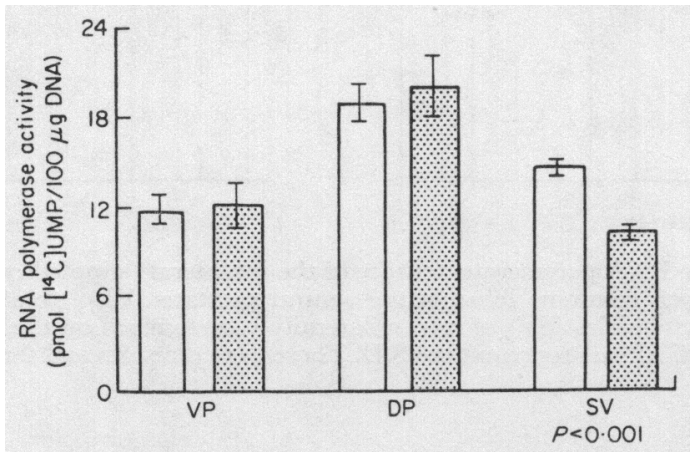

TexT-Fig. 7. The RNA polymerase activity in the contralateral (open columns) and the ipsilateral (stippled columns) lobes of the ventral prostate (VP) and dorsolateral prostate (DP) and seminal vesicles (SV) of rats from which one testis only has been removed and the epididymides are intact. Vertical bars represent the S.D. There were nine rats and three observations/group.

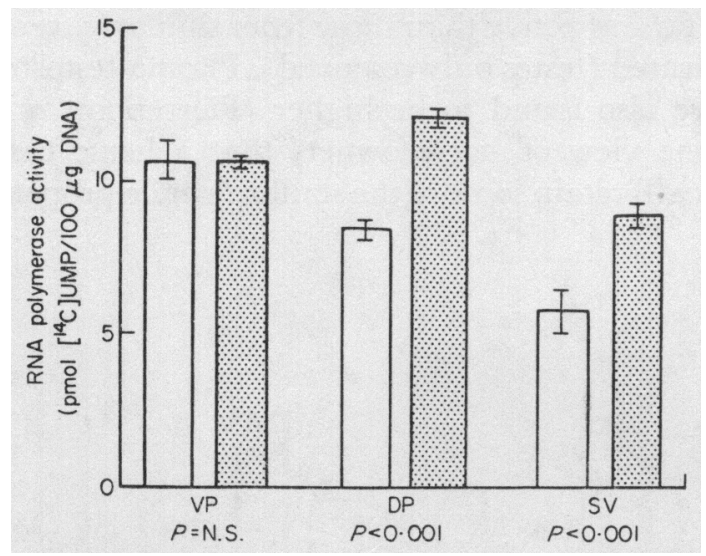

Text-Fig. 8. The comparative influence of unilateral vasectomy (open columns) and contralateral orchidectomy (stippled columns) on the activity of the RNA polymerase enzyme of the respective ventral (VP) and dorsolateral (DP) lobes of the prostate and seminal vesicles (SV) of the rat. Vertical bars represent the S.D. There were nine rats and three observations/group.

These results are similar to those of Skinner \& Rowson (1968a) who showed a unilateral influence of the testis on the ampulla of the ductus deferens by placing one testis in the abdomen, thus reducing its androgen output. The fructose and 
citric acid content was much greater on the 'scrotal' side than on the side of the ectopic testis. These differences were eliminated and even reversed when the ductus deferens on the scrotal side was ligated.

The evidence so far available clearly suggests that the epididymis has an androgenic influence on the prostate as long as the ductus deferens is intact. Testosterone may be concentrated in, and released from, the epididymis along the ductus deferens or it may be metabolized to more active androgens and then redistributed to the prostatic complex. Perhaps more likely is that the androgenmaintained epididymis is capable of using endogenous precursors in the formation of either androgens or other steroids that can be converted in the prostate to active hormones.

\section{POSSIBLE INVOLVEMENT OF THE DEFERENTIAL VEIN}

The cauda epididymidis is confluent with the ductus deferens and the deferential artery and vein are its sole vascular supply and drainage (Greene, 1968). It is, therefore, possible to remove the testis and the caput and corpus epididymidis and leave a vital cauda epididymidis with an attached intact ductus deferens.

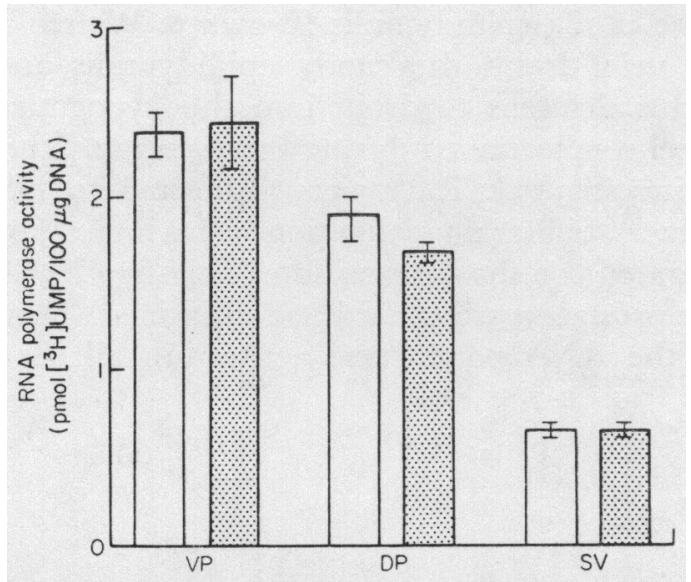

TEXT-FIG. 9. The RNA polymerase activity in the contralateral (open columns) and ipsilateral (stippled columns) lobes of the ventral (VP) and dorsolateral (DP) prostate and seminal vesicles (SV) of the rat after removal of the testis and the caput and corpus epididymidis on one side. Vertical bars represent the S.D. There were nine rats and three observations/group.

Rats were subjected to unilateral orchidectomy with concomitant removal of the caput and corpus epididymidis (Text-fig. $2 \mathrm{~h}$ ). The RNA polymerase activities in the prostate and seminal vesicles did not change significantly (Text-fig. 9) in contrast to the results obtained (Text-fig. 4) when the cauda epididymidis was also removed (Text-fig. 2c).

The cauda epididymidis thus appears to be maintained as much by the contralateral as by the ipsilateral testis. When tritiated testosterone was injected into a testis (Einer-Jensen, 1974), the uptake of radioactivity in the ipsilateral cauda did not vary from that on the contralateral side. Similarly, the reduction 


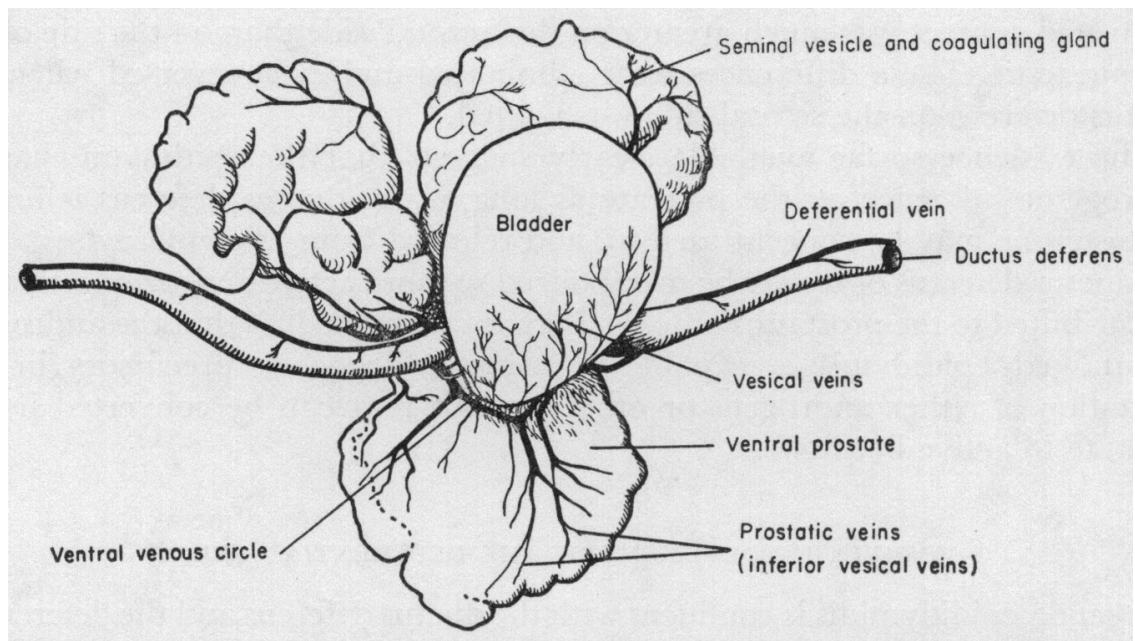

TEXT-FIG. 10. Schematic representation of the vascular drainage of the prostatic plexus, bladder and seminal vesicles. Note the close proximity of entry of the deferential veins to the venous circle at the base of the bladder.

in blood flow to the caput and corpus epididymidis after unilateral castration did not occur in the cauda epididymidis (Brown \& Waites, 1972).

The deferential vein drains the cauda epididymidis and runs along the length of the ductus deferens to drain into the hypogastric vein (Text-fig. 10). Since this vessel was sectioned during the vasectomy the effect of ligation of this vein was investigated. Rats were subjected to bilateral deferential venotomy (vasa intact), bilateral vasoligation (veins intact), bilateral vasectomy (both structures ligated) or sham operation (Text-fig. 2i). After recovery the ventral lobes of the prostate were excised and examined. There was a reduction (Text-fig. 11), in the RNA polymerase activity in all the rats subjected to

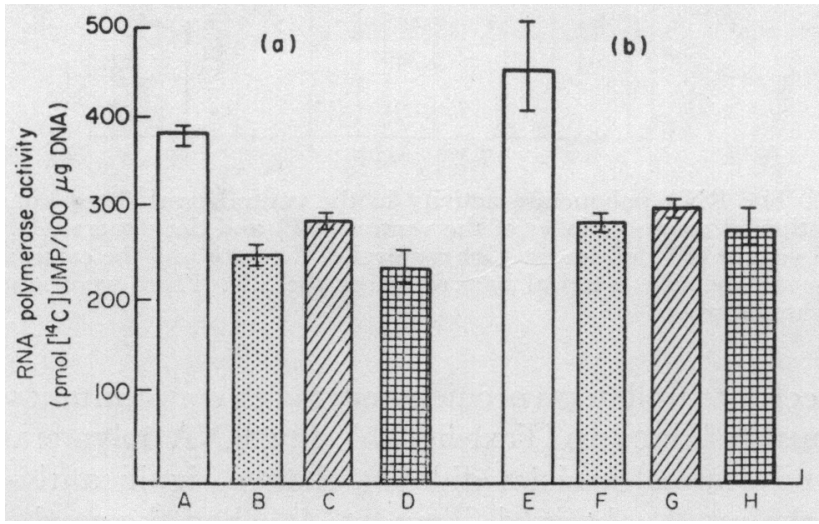

TExT-Fig. 11. The effect on (a) $\mathrm{Mg}^{2+}$-dependent (ribosomal) and (b) $\mathrm{Mn}^{2+}$-dependent (messenger) RNA polymerase activity of the ventral prostate of rats subjected to sham operation (open columns); ligation of both deferential veins (stippled columns), ligation of both ductus deferentes (hatched columns) and both deferential veins and both ductus deferentes (chequered columns). Vertical bars represent the S.D. There were three rats and three observations/group. The $P$ values were: for $\mathrm{A}, \mathrm{B} \ll 0.001 ; \mathrm{A}, \mathrm{C} \ll 0.001 ; \mathrm{A}, \mathrm{D} \sim$ $0.001 ; \mathrm{B}, \mathrm{C} \simeq 0.007 ; \mathrm{B}, \mathrm{D}=$ not significant; $\mathrm{C}, \mathrm{D}=0.007 ; \mathrm{E}, \mathrm{F}=0.005 ; \mathrm{E}, \mathrm{G}=0.007 ; \mathrm{E}, \mathrm{H}=$ $0.006 ; \mathrm{F}, \mathrm{G}=$ not significant; $\mathrm{F}, \mathrm{H}=$ not significant; $\mathrm{G}, \mathrm{H}=$ not significant. 
ligation procedures $(P<0.001)$, especially in those in which the deferential veins had been sectioned. The fertility of rats appeared normal after bilateral deferential venotomy.

When the deferential vein was sectioned on one side (Text-fig. $2 \mathrm{j}$ ) only the activity of the RNA polymerase in the ipsilateral lobes of the prostate was reduced (Text-fig. 12). This was surprising since there was no obvious division between the vascular drainage of the left and right sides.

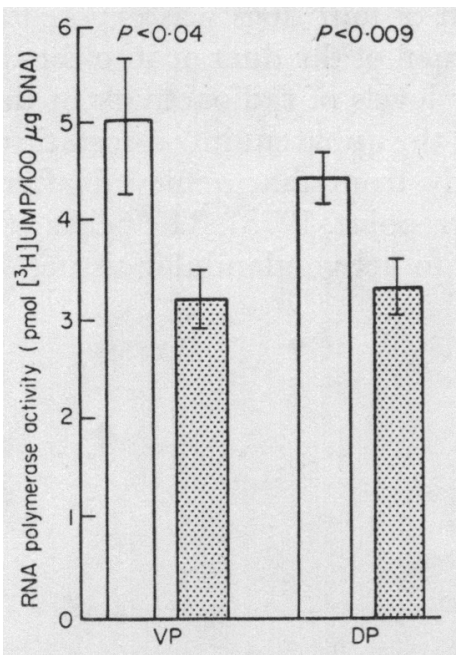

TEXT-FIG. 12. The RNA polymerase activity in the contralateral (open columns) and ipsilateral (stippled columns) lobes of the ventral (VP) and dorsolateral (DP) prostate of the rat after ligation of the right deferential vein. Vertical bars represent the S.D. There were nine rats and three observations/group.

To examine the vascular anatomy of the area a suspension of Neoprene Latex (Harris Ltd, Ludgate, Birmingham) was injected caudally into the posterior venae cavae of 36 dead rats. The bodies were then immersed in acidified formalin solution and dissected under a dissecting microscope. It was demonstrated (Lewis \& Moffat, 1975) that a vascular venous circle exists around the base of the bladder and that the deferential vein enters proximally into the hypogastric vein. No valves were seen in serial sections and an air-bubble can be directed around the venous circle without difficulty. When the animal is at rest, it is assumed that blood from the deferential veins flows into the hypogastric veins and thence to the common iliacs. Retrograde flow can be expected however with a slight but physiological elevation of abdominal pressure caused by such activities as sitting upright, defaecating or fighting. Such a reversal in flow has been observed experimentally. Six rats were anaesthetized and their abdomens opened by a mid-line incision to expose the prostate and the ductus deferentes. A drawn-out glass microcannula was inserted into the deferential vein close to its origin in the cauda epididymidis, and, while the animals were in a $60^{\circ}$ head-up position, $0.5 \mathrm{ml}$ of a filtered saturated solution of Thioflavin (G. T. Gurr Ltd, London) was injected in the direction of blood flow. A maximum of $5 \mathrm{sec}$ was allowed from 
commencing the injection to clamping the prostate at its base to prevent recirculated blood entering the complex. The prostate was removed and frozen and $20 \mu \mathrm{m}$ sections were examined under a Reichert fluorescence microscope. The presence of fluorescent material in the prostatic veins of two out of the six rats was found as shown in Plate 1.

\section{TESTOSTERONE UPTAKE BY THE DOG PROSTATE}

A ductus deferens of each of four dogs was exposed and tritiated testosterone infused into either the lumen of the duct or into the deferential vein. Although on these occasions higher levels of radioactivity in the prostate were achieved after the venous infusions, the apparent intraprostatic distribution (Text-fig. 13) did not differ significantly from that achieved after vasal administration as described previously (Pierrepoint, 1975). The peaks of radioactivity may correspond to blood vessels or to active glandular tissue.

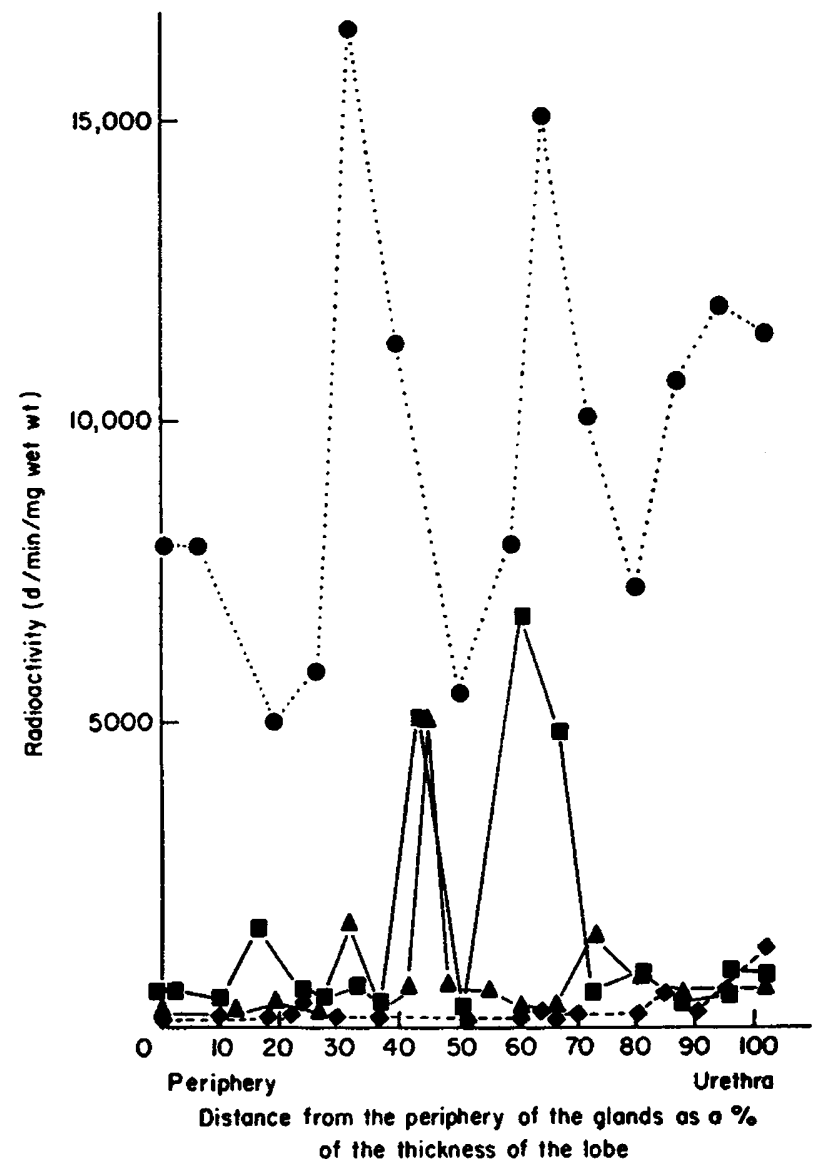

Text-Fig. 13. The distribution of radioactivity in the ipsilateral lobes of the dog prostate after the infusion of tritiated testosterone through a ductus deferens or through the vein of that ductus deferens. The results are from four dogs, two venous infusions and two vasal. $\Delta \uparrow, 100 \mu \mathrm{Ci}\left[{ }^{3} \mathrm{H}\right]$ testosterone via the ductus; $\square, 100 \mu \mathrm{Ci}\left[{ }^{3} \mathrm{H}\right]$ testosterone via the deferential vein; $0,90 \mu \mathrm{Ci}\left[{ }^{3} \mathrm{H}\right]$ testosterone via the deferential vein. 
PLATE

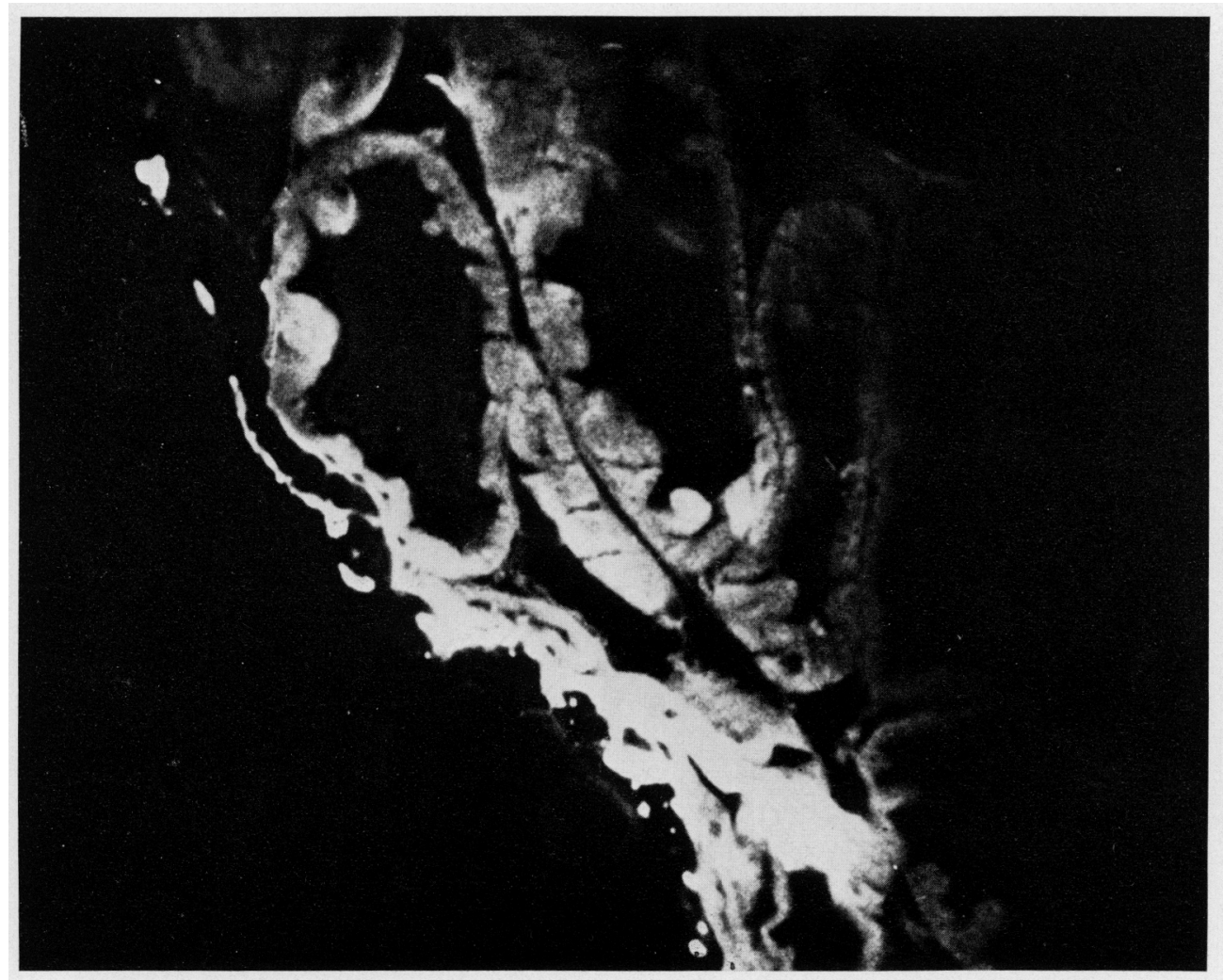

Demonstration of fluorescence in the veins of the ventral prostate after the infusion of Thioflavin along a deferential vein. $\times 125$. 
Blood levels of testosterone in the deferential, radial and testicular veins of the dog and in the deferential and jugular veins of the rat were evaluated by the radioimmunoassay method of Hillier et al. (1973). The results are shown in Table 2. Pierrepoint et al. (1975) have previously shown that testosterone is the predominant $\mathrm{C}_{19}$-steroid in canine deferential vein plasma and reached levels equivalent to those in the testicular vein. Peripheral levels of this androgen are similar in the dog and the rat but in rats the ratio of the levels in the deferential vein to those in the general circulation is approximately $5: 1$ compared to 150:1 in dogs.

The hypothesis that there may be a predisposing factor (the anatomical relationship to the prostate of the point of entry of the ductus deferentes into the urethra) permitting prostatic hyperplasia in man and dog may now be modified. The level of androgens in the deferential vein may be important since blood flowing from this vessel might, in certain circumstances, enter the prostatic vessels.

Table 2. Testosterone levels in blood from various vessels of the dog and rat as measured by radioimmunoassay

\begin{tabular}{lccccc}
\hline & \multicolumn{5}{c}{ Testosterone (ng/ml plasma) } \\
\cline { 2 - 6 } & $\begin{array}{c}\text { Radial } \\
\text { vein }\end{array}$ & $\begin{array}{c}\text { Jugular } \\
\text { vein }\end{array}$ & Heart & $\begin{array}{c}\text { Testicular } \\
\text { vein }\end{array}$ & $\begin{array}{c}\text { Deferential } \\
\text { vein }\end{array}$ \\
\hline Dog 1 & - & - & - & 181 & 185 \\
Dog 2 & 1.38 & - & - & - & $10 \cdot 6$ \\
Dog 3 & 0.06 & - & - & - & 90.5 \\
Dog 4 & $1 \cdot 66$ & - & - & 216.4 & $190 \cdot 6$ \\
Dog 5 & - & - & - & 472.8 & 236.3 \\
Rat 1 & - & - & 0.91 & - & 6.32 \\
Rat 2 & - & 1.12 & - & - & 2.81 \\
\hline
\end{tabular}

Gloyna et al. (1970) have shown that there was a fivefold increase in the concentration of $5 \alpha$-dihydrotestosterone in the hypertrophied prostate of the dog compared with that in normal dogs and yet neither the rate of formation of this steroid from testosterone nor its catabolism had apparently changed. The method used for assessment of the production rate of this androstanolone was essentially an extrapolation from the activity of $5 \alpha$-reduction of testosterone. As the deferential vein carries a higher proportion of $5 \alpha$-reduced compounds than peripheral blood (Pierrepoint et al., 1975) the activity of the $5 \alpha$-reductase in the prostate and any changes that take place with age may only be as important as similar levels and changes in the $3 \alpha$ - and/or $17 \alpha$-hydroxysteroid dehydrogenases. These would promote the formation of what appears to be the specific androgen for the dog prostate, $5 \alpha$-androstane-3 $\alpha, 17 \alpha$-diol (Evans \& Pierrepoint, 1975). Increased levels of $5 \alpha$-reduced steroids from the epididymis or enhanced steroid dehydrogenases in the prostate would result in the accumulation of this active androgen in the prostate gland. 


\section{GONGLUSIONS}

The results of the investigations described support the hypothesis that there is a direct control of the prostate by way of the ductus deferens. This control appears to act in an essentially unilateral manner and depends upon a viable cauda epididymidis, the ductus deferens and the deferential vein. Blood from thedeferential vein of the rat can flow in a retrograde manner into the vessels draining the prostate and, although this phenomenon has not been observed directly in the dog, the relative levels of androgens in this vein in the two animals promotes a continuum of the hypothesis to regard this vessel as a possible source of androgens in the aetiology of prostatic hypertrophy.

The possibility of yet another local controlling system in the body is an exciting prospect and its demonstration follows closely upon that of the uteroovarian transfer of prostaglandin $\mathrm{F}_{2 \alpha}$ that brings about luteolysis (McCracken et al., 1971), and the androgen-binding protein of the seminiferous tubules (Hansson et al., 1975). Not only do these pathways seem logical when brought to light but may also provide means for the direct intervention in specific organ physiology.

\section{ACKNOWLEDGMENTS}

The authors wish to thank the Tenovus Organisation, Cardiff, for their generous financial support. They are grateful to Miss Barbara John and Miss Gail Harvey for their skilled technical assistance and $\mathrm{Dr}$ Meriel Golder and $\mathrm{Mr}$ D. W. Wilson for evaluating the statistics. Mr Brian Joyce kindly measured the levels of plasma testosterone and $\mathrm{Mr} \mathrm{D}$. Mulcuck gave invaluable help in the theatre.

\section{REFERENCES}

Alexander, N.J. (1972) Vasectomy: long-term effects in the rhesus monkey. J. Reprod. Fert. 31, 399406.

Bashirklahi, N., Chader, G.T. \& Villee, C.A. (1969) Effects of dihydrotestosterone on the synthesis of nucleic acid and ATP in prostatic nuclei. Biochem. biophys. Res. Commun. 37, 976-981.

Brown, P.D.C. \& Wartes, G.M.H. (1972) Regional blood flow in the epididymis of the rat and rabbit: effect of efferent duct ligation and orchidectomy. F. Reprod. Fert. 28, 221-233.

Davies, P. \& GriffrThs, K. (1973a) Hormonal effect in vitro on ribonucleic acid polymerase in nuclei isolated from human prostatic tissue. F. Endocr. 59, 367-368.

Davies, P. \& Grifriths, K. (1973b) Stimulation of ribonucleic acid polymerase activity in vitro by prostatic steroid-protein complexes. Biochem. F. 136, 611-622.

Davies, P., Fahmy, A.R., Pierrepoint, G.G. \& Gripriths, K. (1972) Hormonal effects in vitro on prostatic ribonucleic acid polymerase. Biochem. F. 129, 1167-1169.

EINER-JENSEN, N. (1974) Local recirculation of injected $\left[{ }^{3} \mathrm{H}\right]$ testosterone from the testis to the epididymal fat pad and the corpus epididymidis in the rat. $\mathcal{7}$. Reprod. Fert. 37, 145-148.

Evans, C.R. \& Pierrepoint, C.G. (1975) Demonstration of a specific cytosol receptor in the normal and hyperplastic canine prostate for $5 \alpha$-androstane-3 $\alpha, 17 \alpha$-diol. F. Endocr, 64, 539-548.

FANG, S. \& Liao, S. (1971) Androgen receptors. Steroid- and tissue-specific retention of a $17 \beta$-hydroxy$5 \alpha$-androstan-3-one-protein complex by the cell nuclei of ventral prostate. $\mathcal{F}$. biol. Chem. 246, $16-24$.

Flickinger, C.J. (1973) Ultrastructure of the rat testis after vasectomy. Anat. Rec. 174, 477-494.

GLOYNA, R.E., SirTERI, R.K. \& WILSON, J.D. (1970) Dihydrotestosterone in prostatic hypertrophy. II. The formation and content of dihydrotestosterone in the hypertrophic canine prostate and the effect of dihydrotestosterone on prostate growth in the dog. $\mathcal{F}$. clin. Invest. 49, 1746-1753.

Greene, E.C. (Ed.) (1968) Anatomy of the Rat. Hafner, New York. 
Hancock, R.L., Zelis, R.F., Shaw, M. \& Williams-Ashman, H.G. (1962) Incorporation of ribonucleoside-triphosphates into ribonucleic acid by nuclei of the prostate gland. Biochim. biophys. Acta 55, 257-260.

Hansson, V., Weddington, S.G., McLean, W.S., Smith, A.A., Nafeh, S.N., French, F.S. \& Ritzen, E.M. (1975) Regulation of seminiferous tubular function by FSH and androgen. $\mathcal{F}$. Reprod. Fert. 44, 363-375.

Heller, G.V. \& Rothchild, I. (1974) The influence of the surgical technique used for vasectomy on testis function in rats. J. Reprod. Fert. 39, 81-84.

Hillier, S.G., Brownsey, B.G. \& CAmeron, E.H.D. (1973) Some observations on the determination of testosterone in human plasma by radioimmunoassay using antisera raised against testosterone3-BSA and testosterone-11 $\alpha$-BSA. Steroids 21, 735-754.

KothaRI, L.K. \& Mishra, P. (1973) Histochemical changes in the testis and epididymis after vasectomy. Int. F. Fert. 18, 119-125.

LEwis, M.H. \& Moffat, D.B. (1975) The venous drainage of the accessory reproductive organs of the rat with special reference to prostatic metabolism. 7. Reprod. Fert. 42, 497-502.

Liao, S., Leininger, K.R., SAgher, D. \& Barton, R.W. (1965) Rapid effect of testosterone on ribonucleic acid polymerase activity of rat ventral prostate. Endocrinology 77, 763-765.

MaCracken, J.A., BaIrd, D.T. \& Goding, J.R. (1971) Factors affecting the secretion of steroids from the transplanted ovary of the sheep. Recent Prog. Horm. Res. 27, 537-582.

Mainwaring, W.I.P. \& Peterken, B.M. (1971) A reconstituted cell-free system for the specific transfer of steroid-receptor complexes into nuclear chromatin isolated from rat ventral prostate gland. Biochem. F. 125, 285-295.

Mainwaring, W.I.P., Mangan, F.R. \& Peterken, B.M. (1971) Studies on the solubilised ribonucleic acid polymerase from rat ventral prostate gland. Biochem. 7. 123, 619-628.

Mann, T. (1964) The Biochemistry of Semen and of the Male Reproductive Tract, p. 326. Methuen, London.

Moore, C.R. \& Quick, W.J. (1924) Properties of the gonads as controllers of somatic and psychical characteristics. VII. Vasectomy in the rabbit. Am. F. Anat. 34, 317-336.

Nalbandov, A. V. (1964) Reproductive Physiology, 2nd edn. W. H. Freeman \& Co., San Francisco.

Neaves, W. B. (1974) The rat testis after vasectomy. F. Reprod. Fert. 40, 39-44.

O'Connor, J.J. (1950) Cutting a horse 'proud'. In Dollar's Veterinary Surgery, General, Operative and Regional, Pt 11, p. 376, 4th edn. J. J. O'Connor. Baillière, Tindall \& Cox, London.

Pierrepoint, G.G. (1975) Does hormone transfer along the vasa deferentia contribute to the control of prostatic function and could it be a factor in the aetiology of prostatic hyperplasia? In Normal and Abnormal Growth of the Prostate. Ed. M. Golan, Charles C. Thomas, Illinois. (in press).

Pierrepolnt, C.G. \& Davies, P. (1973) The effect of vasectomy on the activity of prostatic RNA polymerase in rats. 7. Reprod. Fert. 35, 149-152.

Pierrepoint, C.G., Davies, P. \& Wilson, D.W. (1974) The rôle of the epididymis and ductus deferens in the direct and unilateral control of the prostate and seminal vesicles of the rat. F. Reprod. Fert. 41, 413-423.

Pierreponvt, G.G., Davies, P., Millington, D. \& John, B.M. (1975) Evidence that the deferential vein acts as a local transport system for androgen in the rat and the dog. F. Reprod. Fert. 43, 293303.

Rakha, A.M. \& Igboeli, G. (1971) Pituitary gonadotrophins (follicle-stimulating hormone and interstitial cell-stimulating hormone) and seminal vesicular fructose after long-term vasectomy in bulls. Fert. Steril. 22, 581-583.

SkINNER, J.D. \& Rowson, L.E.A. (1968a) Some effects of unilateral cryptorchism and vasectomy on sexual development of the pubescent ram and bull. 7. Endocr. 42, 311-321.

SkinNer, J.D. \& Rowson, L.E.A. (1968b) Effects of testosterone injected unilaterally down the vas deferens on the accessory glands of the ram. F. Endocr. 42, 355-356.

SMrTH, G. (1962) The effects of ligation of the vasa efferentia and vasectomy on testicular function in the adult rat. 7. Endocr. 23, 385-399.

Steggles, A.W., Spelsberg, T.C., Glasser, S.R. \& O'Maldey, B.W. (1971) Soluble complexes between steroid hormones and target tissue receptors bind specifically to target tissue chromatin. Proc. natn. Acad. Sci. U.S.A. 68, 1479-1482.

Thakur, A.N., Sheth, A.R. \& RAo, S.S. (1972) Biochemical studies on rat testes and sex accessory organs after vasoligation operation. Fert. Steril. 23, 834-837.

WALLACE, C.S. (1905) The results of castration and vasectomy upon the prostate gland in the enlarged and normal condition. Trans. Path. Soc. Lond. 56, 80-106.

Williams-Ashman, H.G., Liao, S., Hancock, R.L., Jurkowitz, L. \& Silverman, D.A. (1964) Testicular hormones and the synthesis of ribonucleic acids and proteins in the prostate gland. Recent Prog. Horm. Res. 20, 247-292. 